\title{
Entrepreneurial Intention of Young Generation in Metropolis
}

\author{
Santirianingrum Soebandhi ${ }^{1}$, Sugito Muzaki ${ }^{2}$, Agus Sukoco ${ }^{3}$ \\ ${ }^{1}$ santirianingrum@narotama.ac.id \\ ${ }^{2}$ sugito.muzaqi@narotama.ac.id \\ 3 agus.sukoco@norotama.ac.id \\ ${ }^{1,3}$ Faculty of Economics and Business, Narotama University, Surabaya, Indonesia \\ ${ }^{2}$ Faculty of Teachery and Educational Science, Narotama University, Surabaya, Indonesia \\ Email : santirianingrum@narotama.ac.id, sugito.muzaqi@narotama.ac.id, \\ agus.sukoco@norotama.ac.id

\begin{tabular}{|c|c|c|}
\hline Accepted : & Reviewed : & Published : \\
January, 11 2018 & February, 13 2018 & March,30 2018 \\
\hline
\end{tabular}

\begin{abstract}
Purpose: This study is aimed to analyze entrepreneurial intention of youth during the process towards young entrepreneur that is intellectually, mentally, and economically independent, approached by planned behavior principles.

Design/methodology/approach: The quantitative research method with three variables (attitude, social norm and behavior) was used as the predictor of young entrepreneurial intention. The respondents are 127 young adult aged 18-28 years old with High School/Vocational School as their minimum education and domiciled in Surabaya and Sidoarjo. Likert scale with 5 levels was used as the research questionnaire, distributed with two methods that are filling out the questionnaire by online and manually.

Findings: The result shows that attitude, social norm and behavior variable give positive contribution in creating young generation entrepreneurial intention in metropolis. Indicator which gives strong contribution in triggering entrepreneurial intention of young generator is that the paradigm of being entrepreneur is able to give benefits, satisfaction and as a choice. Social factor encouraging establishing the businesses are friends and relatives. Behaviors impelling it are the feeling of being able and having enough knowledge in starting the business as well as able to manage the business. The constraints are coming from little encouragement of family and low belief for getting success.
\end{abstract}

Research limitations/implications: This study was conducted in two urban areas in East Java. Further research can be done on a wider area.

Practical implications: Entrepreneurial intention of youth is unique inasmuch as it has environment and complexity characteristics which enables to give impact towards society.

Originality/value: This study focuses on urban areas with young adults respondents which can provide new references to factors that may encourage or hamper their interest in becoming entrepreneurs

Paper type: Research paper

Keyword: young entrepreneur, attitude, social norm, behavior, entrepreneurial intention, urban areas 


\section{INTRODUCTION}

Indonesian young generation has a challenge and opportunity to be an entrepreneur. Although, in 2016, the number of business in Indonesia reached 3.1\% of total population which means it has exceeded the minimum limit of a country's entrepreneurial ratio, i.e. 2\% (Ministry of Cooperatives and SMEs, 2017), however Indonesia is still left behind from other ASEAN countries which in 2015 has reached 7\% for Singapore and 5\% for Malaysia (Litbang Kompas, 2015). To catch up this condition, Indonesian government sets up the targets to increase the percentage of Indonesian entrepreneurs to at least 4\% of the total population by 2017 (Ministry of Cooperatives and SMEs, 2017). It means that Indonesia still needs about 5.8 million of young entrepreneur to win ASEAN Economic Community (AEC) (Tempo, 2016).

The development of Micro, Small, and Medium Enterprises (MSMEs) in the economic context of ASEAN becomes one of the paramount programs of AEC in the ASEAN Economic Community Blueprint 2025 (Soekartawi, 2016). Therefore, entrepreneurship development as the manifestation to support MSMEs development is still required to Indonesian Human Resources that is able to compete in AEC era. The challenge faced is to change the mindset and desire of young generation from job-seeker paradigm to be entrepreneur to produce new business opportunities or to develop the existing business. Mindset changing can be initiated from intention changing which ultimately leads to entrepreneurial behavior as an entrepreneur. In Indonesia, the intention to become an entrepreneur is still very low. Based on Figure 1, college graduates who want to become entrepreneurs are only $6.4 \%$ and High School graduates is only $22.4 \%$, the rest prefers to become employees (MR, 2016).

Economic Globalization has directed world trade system to free market system. Free market is the implementation of the economic market through free competition that is, everyone will be exposed to competition that is open, and thereby the winner of the competition will survive in the global market (Surachman, 2012). In this free market era, boundaries between countries are becoming thinner and more convenience is given in conducting business, such as the ease for foreign investors to invest in Indonesia (Simandjuntak, 2004). Indonesia's readiness in facing the AEC has become a prominent topic of discussion on every occasion. Competitiveness becomes one of the keys of Indonesia's success in facing the AEC. In the ranking of the World Economic Forum (WEF), Indonesia's economic competitiveness ratings are down this year, from the $34^{\text {th }}$ place last year to $37^{\text {th }}$ from 140 countries. In the Global Competitiveness Report 2015-2016 released by WEF, Indonesia's competitiveness lost to three neighbors, Singapore in $2^{\text {nd }}$ rank, Malaysia ranked $18^{\text {th }}$ and Thailand at $32^{\text {th }}$. In ASEAN, Indonesia is ahead of the Philippines $\left(47^{\text {th }}\right)$, Vietnam $\left(56^{\text {th }}\right)$, Laos $\left(83^{\text {th }}\right)$, Cambodia $\left(90^{\text {th }}\right)$, and Myanmar $\left(131^{\text {th }}\right)$ (Supriadi, 2015).

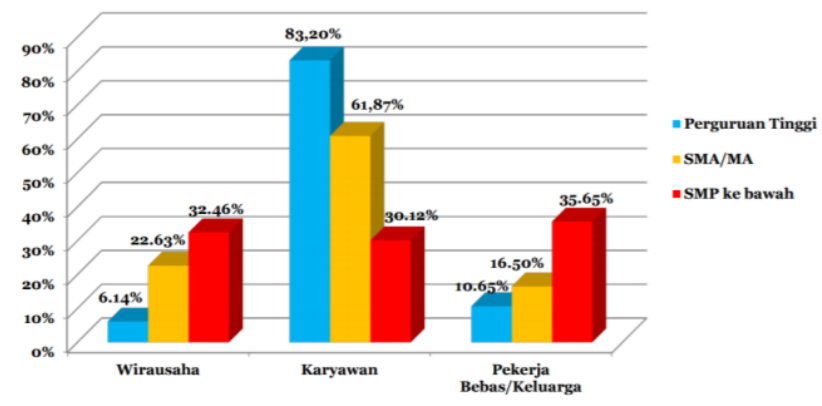

Figure 1 Entrepreneurial Intention Based on Education Level Source: (MR, 2016)

Indonesia has only few entrepreneurs, while on the other hand the challenge of free market, especially AEC is bigger. Hence, serious effort is needed to take to increase the number of entrepreneurs in Indonesia. Efforts to increase entrepreneurship in Indonesia should start from the basic thing, which is to build the intention of Indonesian people to do a business. Based on those aforementioned backgrounds described, it is considered that research analyzing how to shape the intention of Indonesian youth in entrepreneurship is important GDB. University students as a young generation of Indonesia aged below 30 years old is the nation's next generation, so 
it is possible to do adaptation and adjustment and even upgrade at higher level. They will be as the object of research in the next stage.

According to Theory of Planned Behavior (TBP) stating that individual intention to conduct a behavior is a variable that causes the certain behavior (Ajzen, 1991). Intention also represents how though an individual audaciously tries, intention shows how big the effort planned by an individual to be carried out. TBP is used by many researchers to analyze entrepreneurship behavior and its intention; the researchers are willing to analyze factors contributing to individual's intention to undertake enterprise.

Considering a variety of backgrounds explained above, conducting research exploring how to shape Indonesian youth's intention in doing enterprise can be said as a paramount importance. Therefore, the numbers of young entrepreneurs in Indonesia increases, which are expected to raise the national GDB and even create human resources who are capable to compete in AEC and global competition in general. University students as a young generation of Indonesia aged below 30 years old is the nation's next generation, so it is possible to do adaptation and adjustment and even upgrade at higher level. They will be as the object of research in the next stage.

Entrepreneur can be defined as someone who create something new, manage production process, take risk and deal with economic uncertainty of company (Havinal, 2009). While entrepreneurship is a control, nature resources distribution and innovative economic organization in order to get benefits and growth in risking environment condition and uncertainty (Dollinger, 2008). Theory of planned behavior (TPB) is a theory developed by Ajzen as the steps in work improvement of Fishbein and Ajzen theory, named Theory of Reason Action (TRA). Both of these theories have the same focus that is, about individual's intention to do certain behavior. Intention are an indication of how hard people to try and how much effort the individual will spend to perform a behavior. Fishbein \& Ajzen (1975) postulated in TRA that there are two determinants of intentions, namely personal attitudes and subjective norms. Attitude is a positive or negative evaluation of an individual towards a particular behavior. While the subjective norm is a person's perception of social pressure to perform or not to perform certain behaviors. However, Ajzen argues that the TRA has not been able to explain behavior that is not completely under individual's control. Therefore, in TPB Ajzen adds one factor determining the intention of perceived behavioral control which is the individual's perception towards possessed control related to certain behavior (Ajzen, 2005).

Models about individual desires are included in the scope of Social Cognitive Theory proposed and developed by Bandura (1986). The core of this theory is that individuals are able to influence their behavior (Ratten \& Ratten, 2007). This theory proposes a reference to understand, predict, and change human behavior (Davis \& Peake, 2014). Thus the intention model will contribute to the area of behavior prediction. Intention represents a person's motivation to accomplish what has been planned and what has been decided (Conner \& Armitage, 1998). Entrepreneurial intention is someone's motivation to make a business plan and prepare himself to start a business. Entrepreneurial intention is as a person's self-assurance that they intend to set up a new business venture and consciously plan to do so at some point in the future (Thompson, 2009). The entrepreneurial intention is not just a yes or no question but the intention to establish a business that can start from a very low, zero, to a very high level in the business (Thompson, 2009). Various research emphasize that intention is a strong predictor of actual behavior in planned activities (Conner \& Armitage, 1998; Gelderen et al., 2008)

The writer argues that the decision to become an entrepreneur and set up a business involves careful planning and a very high thinking process (Autio, Keeley, Klofsten, Parker, \& Hay, 2010). Entrepreneurship can be viewed as an appropriate topic of planned intentional behavior and so it can be applied to the intention model (Autio et al., 2010). Especially in entrepreneurship education programs declares that intentions can be used that is, "intentions have proven to be the best predictor of planned behavior" (Krueger, Reilly, \& Carsrud, 2000).

TPB consists of 3 main elements: 1) Behavioral intention that depends on 2) subjective norms and 3) attitudes. The stronger the positive attitude toward behavior and the power of social norms toward behavior, the stronger the intention of behaving. If there is a high intention, the individual tends to perform certain behaviors. In the concept, intention has a big contribution to the formation of individual's behavior. Meanwhile, intention is influenced by attitude toward behavior, subjective norm, and perceived behavioral control.

Several studies on attitude toward behavior and intention toward behavior found that there was a positive and significant impact between attitude towards behavior against intention toward behavior (Aslam, Awan, \& Khan, 2012; Astuti \& Martdianty, 2012; Hussain \& Norashidah, 2015; Jiang, Zhao, \& Li, 2010; Karali, 2013; Karimi, Biemans, Lans, Chizari, \& Mulder, 2016; Malebana \& Swanepoel, 2015). Besides, there are also some prior research inconsistent with the above research that attitude toward behavior has no significant effect on intention toward behavior (Karimi et al., 2016). Therefore, we propose hypothesis mentioned as follows:

Entrepreneurial Intention of Young Generation in Metropolis

Santirianingrum Soebandhi, Sugito Muzaki, Agus Sukoco 
H1 : attitude toward behavior has positive and significant impact on entrepreneur intention

Other research found that there is a significant impact between social norm on intention toward behavior (Aslam et al., 2012; Astuti \& Martdianty, 2012; Hussain \& Norashidah, 2015; Jiang et al., 2010; Karali, 2013; Karimi et al., 2016; Malebana \& Swanepoel, 2015). While Krueger et al. (2000) claimed different result with aforementioned findings that is, Social Norm (SN) has insignificant impact on Entrepreneur Intention. Therefore, the hypothesis is mentioned below:

H2 social norm has positive and significant impact on entrepreneur intention

There is a significant impact of perceived behavioral control on intention toward behavior (Aslam et al., 2012; Astuti \& Martdianty, 2012; Hussain \& Norashidah, 2015; Karali, 2013; Karimi et al., 2016; Malebana \& Swanepoel, 2015). While Jiang et al. (2010) found that there is no significant impact of behavioral control on intention toward behavior.

H3 : perceived behavior control has positive and significant impact on entrepreneur intention

\section{METHODOLOGY}

\section{A. Conceptual Framework}

This conceptual framework is to test variables influencing entrepreneur behavior, using basic concept of TPB developed by the researcher, thereby entrepreneur behavior is measured using variable tested that is, attitude toward the behavior, social norm, perceived behavioral control and entrepreneur intention. Figure of conceptual framework is in this following.

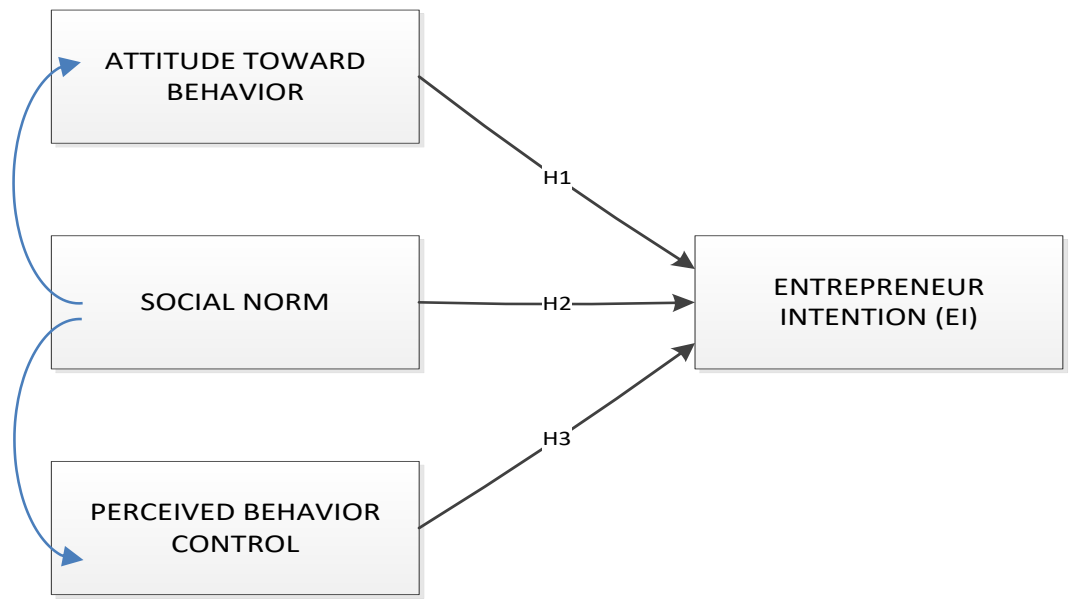

Figure 2 Conceptual Framework

\section{B. Data Collection}

The population of this study was young people living in Surabaya city, with the age range between 18 to 35 years old, with minimum education of high school and equal.

The samples and respondents were young people in Surabaya and Sidoarjo with age between 18 years to 35 years as many as 127 people. Data collection was conducted during January-March 2017. The research questionnaire were distributed to the respondents in two ways that is by filling the questionnaire directly on the print form that has been provided and the second by filling out the form provided online.

Research Indicator:

Attitudes toward Behavior (Linan, 2009)

Entrepreneurial Intention of Young Generation in Metropolis

Santirianingrum Soebandhi, Sugito Muzaki, Agus Sukoco 
1. Intentioned in being an entrepreneur

2. Loving to start a business, If I had the opportunity and resources

3. Being an entrepreneur would give great satisfaction

4. Being entrepreneur becomes the main choice

Perceived Behavioral Control (Linan, 2009)

1. Feeling easy to start a firm and keeping it viable

2. Feeling ready to start a decent business.

3. Being able to control the creation process of a new business.

4. Having enough knowledge required to start a business.

5. Understand to develop business project

6. Believing to have a high chance of being successful.

Social Norms (Linan, 2009)

1. My immediate family would approve my decision to start a business.

2. My friends would approve my decision to start a business.

3. My colleagues would approve my decision to start a business.

4. My close relatives would approve my decision to start a business.

Entrepreneur Intention (Linan, 2009)

1. Being ready to do anything to be an entrepreneur.

2. Entrepreneur becomes the main profession

3. Making every effort to start and run my own business.

4. Determined to create a business venture in the future

5. Being serious in thinking to start a business

6. Intention to start business one day ahead

7. Search all the information to start business one day ahead

\section{RESULTS AND DISCUSSION}

\section{A. Characteristics of Respondents}

Data collection was done by distributing the questionnaires to the young generation in Surabaya and Sidoarjo, East Java, Indonesia. Respondents as many as 127 people, the majority is from Surabaya with distribution: Surabaya 82 people (64.6\%) and from Sidoarjo 45 people (35.4\%). Characteristics of respondents by sex was dominated by women compared to men i.e., men 39 people (30.7\%) and women 88 people $(69.3 \%)$. Average age of respondents is 19 years old, 17 years old as the minimum age and 28 years as the maximum age. Age of respondents of $88 \%$ is between the ages of 18,19 and 20 years old, the remaining $12 \%$ are 17,21 to 28 years old.

Characteristics of respondents according to the education level have met the requirements that all the respondents have completed high school education and study in colleges with second and fourth semester students are $89.9 \%$ the remaining sixth, seventh and eighth semester students are respectively $6.3 \%, 2.4 \%$ and $1,6 \%$..

\section{B. Data Analysis}

The data is processed using Smart PLS 2.0, to test the research hypothesis. The research variables used consist of one endogenous variable of entrepreneur intention and three exogenous variables namely Attitude, Social Norm and Behavior Control. Testing phase starts from outer model testing and continued to inner model testing, meaning to ensure that model which is used in fulfilling specified research requirement.

\section{C. $\quad$ Validity Test}

Validity test is done by looking at the loading factor of each indicator to the construct provided that if the loading factor value is more than 0.5 then it is deemed to have fulfilled the requirements and can be used in the next test. The result of validity test for all construct indicators is as mentioned in the following table: 
Table 1 Validity Test of Indicators

\begin{tabular}{ccc}
\hline Construct/ & Loading Factor & \\
Indicator & & \\
\hline ATTITUDE & 0.622477 & Valid \\
A1 & 0.862943 & Valid \\
A2 & 0.787738 & Valid \\
A3 & 0.852156 & Valid \\
A4 & 0.835889 & Valid \\
A5 & & \\
SOCIAL NORMS & 0.755115 & Valid \\
N1 & 0.90477 & Valid \\
N2 & 0.854234 & Valid \\
N3 & 0.909953 & Valid \\
N4 & & \\
B1 & 0.593589 & Valid \\
B2 & 0.782551 & Valid \\
B3 & 0.827169 & Valid \\
B4 & 0.811118 & Valid \\
B5 & 0.707573 & Valid \\
B6 & 0.619987 & Valid \\
BEHAVIOR & & \\
M1 & 0.76605 & Valid \\
M2 & 0.795704 & Valid \\
M3 & 0.838858 & Valid \\
M4 & 0.85216 & Valid \\
M5 & 0.907354 & Valid \\
M6 & 0.917098 & Valid \\
M7 & 0.861037 & \\
\hline
\end{tabular}

The constructor indicator based on the total loading factor value is declared valid, with a loading value greater than 0.5 . The minimum loading factor is 0.6079 for the indicator to B6, so that all indicators can be used in the next test.

\section{Discriminant Validity}

Discriminant validity is used to test reflective indicators. The reflective indicator is valid if the loading factor of the construct is greater than the loading factor of the other constructs. Another way to test Discriminant validity is to do square root test of average variance extracted (AVE), provided that if AVE value is more than 0.5 it is valid. Discriminant validity test results for reflective indicators of research variables are as follows:

Table 2 Result of square root test of average variance extracted (AVE)

\begin{tabular}{lc}
\hline & AVE \\
\hline Attitude & 0.635512 \\
Behavior & 0.531983 \\
Entrepreneur Intention & 0.722226 \\
Social Norm & 0.736634 \\
\hline
\end{tabular}


All discriminant validity test get valid indicators, the loading factor value of the construct is greater than the loading factor of other constructs. The next step by looking at the value of AVE, test results are obtained as follows. The test results show that all constructs have an AVE value greater than 0.5 , so all the variables are valid.

\section{E. Reliability Test}

Reliability test of the construct by seeing at the value of composite reability and Cronbachs Alpha indicator to the construct. The values required to meet reliability are composite reability 0.7 and Cronbachs Alpha 0.6. Reliability test is done by looking at the value of composite reliability and Cronbach Alpha from indicator block that measure the construct.

The reliability test results get that the Composite Reliability value for all constructs is greater than 0.7 and the Cronbachs Alpha value is greater than 0.6. The value of Composite Reliability is at least equal to 0.870361 and the minimal value of Cronbachs Alpha is 0.820428 for Behavior construct. so it satisfies the whole construct of reliability requirement research.

Table 3 Realibility Test with Composite Reliability

\begin{tabular}{lcc}
\hline \multicolumn{1}{c}{ Construct } & Composite Reliability & Cronbachs Alpha \\
\hline Attitude & 0.895941 & 0.854607 \\
Behavior & 0.870361 & 0.820428 \\
Entrepreneur Intention & 0.947741 & 0.935099 \\
Social Norm & 0.917555 & 0.878809 \\
\hline
\end{tabular}

\section{F. $\quad$ Model Structure Test} construct.

Model Structure Test (Inner model test) is done by looking at the results of R Square values on each

Table 4 R Square Test on Model Structure

\begin{tabular}{lc}
\hline \multicolumn{1}{c}{ Konstruk } & R Square \\
\hline Attitude & 0.135964 \\
Behavior & 0.14378 \\
Entrepreneur Intention & 0.663309 \\
Social Norms & \\
\hline
\end{tabular}

R Square test shows that the highest score of Entrepreneur Intention is 0.663309 or $66.33 \%$, it means that Attitude, Behavior and Social Norms in the model as a whole have the ability to predict entrepreneur intention of 0.663309 or $66.3309 \%$. Whereas R square on Attitude and Behavior influenced by Social Norm is relative small that is 0.135964 or $13.5964 \%$ and $14.378 \%$. This explains that the construct of social norm in shaping entrepreneurship through Attitude and Behavior is relatively small at $13 \%$ to $14 \%$.

\section{G. Hypothesis Test}

Hypothesis test is done by comparing $t$ value with $t$ table, with reference value that $t$ value is greater than 1.96 hence the influence between variabel is significant. The direction of the relationship between variables is seen from the values in the Original Sample column $(\mathrm{O})$.

Table 5 Correlation Test and t Test

\begin{tabular}{lcc}
\hline & $\begin{array}{c}\text { Original } \\
\text { Sample }(\mathbf{O})\end{array}$ & $\begin{array}{c}\text { T Statistics } \\
(\text { IO/STERR })\end{array}$ \\
\hline Attitude -> Entrepreneur Intention & 0.5462 & 6.6215
\end{tabular}

Entrepreneurial Intention of Young Generation in Metropolis

Santirianingrum Soebandhi, Sugito Muzaki, Agus Sukoco 


\begin{tabular}{lcc} 
Behavior -> Entrepreneur Intention & 0.3328 & 3.6061 \\
Social Norms -> Attitude & 0.3687 & 3.088 \\
Social Norms -> Behavior & 0.3792 & 3.3637 \\
Social Norms -> Entrepreneur Intention & 0.3842 & 3.4315 \\
\hline
\end{tabular}

Result of $\mathrm{t}$ test for influence between variables tested get the value of $T$ Statistics all above the value of table 1,96. The influence between the variables tested is significant. The value in the Original Sample column gives information of the relation between the variables tested and determines the direction of the positive or negative relation. The test results of Original Sample has positive value of all and the values are between 0.3328 to 0.5462.

The intention of youth entrepreneurs in urban and metropolitan areas is unique because urban communities have different characteristics, more, the environment and metropolitan complexity have an effect on the characteristics of society including young people in urban areas. The urban community tends to be instant and practical. It is predicted to have an effect on entrepreneurial intention among urban youth. This study explores the various factors that are suspected as a driver for youth in entrepreneurship. The three variables used as predictors are attiude, social norm and behavior. Attitude variable is the variable that gives the highest contribution to entrepreneur intention, hereinafter is variable of social norm and variable of behavior give the least contribution to intention of young entrepreneur in Surabaya and its surroundings. However, all variables make a positive contribution in shaping the intention of young entrepreneurs. Respondents are at least 17 years old and a maximum of 28 years old, the average age is 19 years old, so that the average study respondents were very young. Respondents from male sex is $30.7 \%$ and women is $69.3 \%$, so the majority of respondents are women.

Based on the city of origin, $64.6 \%$ of the respondents from Surabaya, and the rest is from Sidoarjo $35.4 \%$. Based on the characteristics of the respondents, this study is more likely on women's gender. Attitude is the variable that gives the highest contribution to entrepreneur intention. The highest attitude variable indicator is the fifth statement, "Among the various options, I prefer to be an entrepreneur" with an average score of 2.24 and a standard deviation of 0.87 . The second order attitude indicator that contributes to the intention of young entrepreneurs is the first statement: "Being an entrepreneur is more beneficial for me". The third order is the fourth indicator "Being an entrepreneur will give me greater satisfaction". From the attitude variable, it is known that the intention of the metropolitan youth in entrepreneurship is because they see that entrepreneurs provide benefits, give satisfaction and become the choice of profession as an entrepreneur.

Social norms give second contribution to entrepreneurial intention. The indicator of social norms, which are contributed, in order, are the third statement, "My college friend would approve me to start a business," then the second statement "Friends would approve me to start a business," then the fourth statement "My close relative would approve me to start a business" and finally the first statement "Family would approve me to start a business". So from the perceived social aspect, good friends, colleagues or playmates in the surrounding community can provide support for entrepreneurship. Furthermore, the relatives also made a good contribution. The family felt less support for the entrepreneurial intentions of the metropolitan youth.

Behavior is the variable that contribute as the lowest rank in shaping the intention of young entrepreneurs, however, the behavior contributes positively to entrepreneurial intention. The first indicator of behavior, "Starting and running a business is not difficult for me" contributes the most. The next contributing indicator is "I know how to develop an entrepreneurial project". Second position, "I have enough knowledge to start a business", as the third position, "I have the ability to control the process of establishing a new company", the fourth position, "I am ready to start a decent company", the fifth and final position is "I believe that I have a chance to succeed". Aspects of behavior of respondents feel not difficult in starting a business, feeling having enough knowledge, have the ability to control the business, and respondents feel that the chances for success is very small.

\section{CONCLUSIONS}

The study of entrepreneurial intention for urban areas with teenagers aged an average of 19 years old, provides a new reference on how they feel the impetus and obstacles to become entrepreneurs. Hypothetically, all hypotheses can be accepted that all the variables studied provide a positive impact on entrepreneur intention. A more in-depth study of the indicators studied, from the aspect of attitude, it is found that entrepreneurs provide benefits, give satisfaction and become the choice of profession as an entrepreneur. The social aspect of

Entrepreneurial Intention of Young Generation in Metropolis

Santirianingrum Soebandhi, Sugito Muzaki, Agus Sukoco 
metropolitan youth found that the highest impetus of being entrepreneur is college buddies, followed by playmates, relatives. More, the family is the least encouragement given for youth becoming entrepreneur. From the behavioral aspect, the youth feel that the strong drive of entrepreneurship is to feel not difficult or able to start a business, have enough knowledge in starting a business, and have the ability to control the business. Nevertheless, the chance for success is felt very small.

In order to increase entrepreneurial intention among youth, especially for adolescent in metropolitan city, things that need attention are encouragement from family and parents. This is most likely because of parent's view that the success of a child if they can complete the study on time, high achievement index and subsequently get a job on a bonafide company. To encourage the growth of young entrepreneurs, it requires awareness from parents regarding to the idea of success definition, which means success does not always have to be an office worker, becoming an entrepreneur as another alternative to success is also a good option, and this is in line with what respondents feel that they feel capable and proud as entrepreneurs. Another thing that is perceived as an obstacle is the low sense of opportunity for success in entrepreneurship. This is a challenge on how to build confidence of young people that there is always a way to succeed, with a lot of learning on entrepreneurs who have been success. Further research is recommended to conduct a more in-depth study about how the perception of parents to the entrepreneurial profession in their children

\section{REFERENCES}

Ajzen, I. (1991). The theory of planned behavior. Organizational Behavior and Human Decision Processes, 50(2), $179-211$

Ajzen, I. (2005). Attitudes, Personality, and Behavior. New York: Open University Press.

Aslam, T. M., Awan, A. S., \& Khan, T. M. (2012). Entrepreneurial Intentions among University students of Punjab a Province of Pakistan. International Journal of Humanities and Social Science, 2(14), 114-120.

Astuti, R. D., \& Martdianty, F. (2012). Students' Entrepreneurial Intentions by Using Theory of Planned Behavior: The Case in Indonesia. The South East Asian Journal Of Management, 6(2), 100-112. http://doi.org/10.21002/seam.v6i2.1317

Autio, E., Keeley, R. H., Klofsten, M., Parker, G. G. C., \& Hay, M. (2010). Entrepreneurial Intent among Students in Scandinavia and in the USA. Journal of Business Systems, Governance and Ethics, 2(2), 145-160. http://doi.org/10.1080/1463244011009463

Bandura, A. (1986). Social foundations of thought and action: A social cognitive theory. Englewood Cliffs, NJ: Prentice-Hall.

Conner, M., \& Armitage, C. J. (1998). Extending the Theory of Planned Behavior: A Review and Avenues for Future Research. Journal of Applied Social Psychology, 28, 1429-1464.

Davis, P. E., \& Peake, W. O. (2014). The Influence of Political Skill and Emotional Intelligence on Student Entrepreneurial Intentions: An Empirical Analysis. Small Business Institute Journal, 10(2), 19.

Dollinger, M. J. (2008). Entrepreneurship: Strategies and Resources. Illinois: Marsh Publications.

Fishbein, M., \& Ajzen, I. (1975). Belief, Attitude, Intention and Behaviour: An Introduction to Theory and Research. Reading MA AddisonWesley, (August), 480. http://doi.org/10.2307/2065853

Gelderen, M. van, Brand, M., Praag, M. van, Bodewes, W., Poutsma, E., \& Gils, A. van. (2008). Explaining entrepreneurial intentions by means of the theory of planned behaviour. Career Development International, $13(6), 538-559$.

Havinal, V. (2009). Management and Entrepreneurship. New Delhi: New Age International.

Hussain, A., \& Norashidah. (2015). Impact of Entrepreneurial Education on Entrepreneurial Intentions of Pakistani Students. Journal of Entrepreneurship and Business Innovation, 2(1), 43-53. http://doi.org/https://doi.org/10.5296/jebi.v2i1.7534

Jiang, X., Zhao, X., \& Li, L. (2010). TPB model and its analysis of agricultural college students' entrepreneurial intentions - Case Study at Agricultural University of Hebei University. Journal of Agricultural University of Hebei (Agriculture and Forestry Education), 4, 469-473.

Karali, S. (2013). The Impact of Entrepreneurship Education Programs on Entrepreneurial Intentions: An Application of The Theory of Planned Behavior. Rotterdam: Erasmus University.

Karimi, S., Biemans, H. J. A., Lans, T., Chizari, M., \& Mulder, M. (2016). The Impact of Entrepreneurship Education: A Study of Iranian Students' Entrepreneurial Intentions and Opportunity Identification. Journal of Small Business Management, 54(1), 187-209. http://doi.org/10.1111/jsbm.12137 
Ministry of Cooperatives and SMEs. (2017). Menteri Puspayoga Target Ratio Kewirausahaan 2017 Capai $4 \%$. Retrieved April 27, 2017, from http://www.depkop.go.id/content/read/menteri-puspayoga-target-ratiokewirausahaan-2017-capai-4/

Krueger, N. F., Reilly, M. D., \& Carsrud, A. L. (2000). Competing models of entrepreneurial intentions. Journal of Business Venturing, 15(5-6), 411-432. http://doi.org/10.1016/S0883-9026(98)00033-0

Litbang Kompas. (2015). Wirausaha Indonesia Tertinggal Jauh. Retrieved April 27, 2017, from http://www.mriresearch-ind.com/berita-249-wirausaha-indonesia-tertinggal-jauh.html

Malebana, M., \& Swanepoel, E. (2015). Graduate entrepreneurial intentions in the rural provinces of South Africa. Southern African Business Review, 19(1), 89-111.

MR, R. (2016). Pengembangan usaha perempuan bagi kesejahteraan keluarga melalui kewirausahaan. Retrieved April 28, 2017, from http://kebudayaan.kemdikbud.go.id/ditkt/wpcontent/uploads/sites/6/2016/11/Presentasi_Pengembangan-Usaha-Perempuan-bagi-KesejahteraanKeluarga-Melalui-Kewirausahaan.pdf

Ratten, V., \& Ratten, H. (2007). Social cognitive theory in technological innovations. European Journal of Innovation Management, 10(1), 90-108.

Simandjuntak, H. B. (2004). The Power of Values in the Uncertain Business World: refleksi seorang CEO. Jakarta: Gramedia Pustaka Utama.

Soekartawi, K. S. (2016). 2016 MASYARAKAT EKONOMI ASEAN 2025. Retrieved April 28, 2017, from http://aeccenter.kemendag.go.id/post/berita/artikel/masyarakat-ekonomi-asean-2025-integrasi-asean-pada10-tahun-mendatang/

Supriadi, A. (2015). WEF: Daya Saing Indonesia Turun ke Peringkat 37 Dunia. Retrieved April 30, 2017, from http://www.cnnindonesia.com/ekonomi/20151002162426-92-82410/wef-daya-saing-indonesia-turun-keperingkat-37-dunia/

Surachman, A. (2012). Pustakawan Asia Tenggara Menghadapi Globalisasi dan Pasar Bebas. Media Pustakawan, (19 (1)). Retrieved from http://www.perpusnas.go.id/magazine/pustakawan-asia-tenggara-menghadapiglobalisasi-dan-pasar-bebas/

Tempo. (2016). Menangkan MEA, Jokowi: RI Perlu 5,8 Juta Pengusaha Muda Baru. Retrieved April 28, 2017, from https://m.tempo.co/read/news/2016/05/23/092773404/menangkan-mea-jokowi-ri-perlu-5-8-jutapengusaha-muda-baru

Thompson, E. R. (2009). Individual Entrepreneurial Intent: Construct Clarification and Development of an Internationally Reliable Metric. Entrepreneurship: Theory and Practice, 33(3), 669-694. http://doi.org/10.1111/j.1540-6520.2009.00321.x 